\title{
DISTRIBUTION OF THE CAUSATIVE AGENTS OF RESPIRATORY TRACT INFECTIONS IN CHILDREN
}

\author{
Mishyna M. ${ }^{1}$, Gonchar M. ${ }^{1}$, Logvinova O. ${ }^{1}$, Isaieva H. ${ }^{1}$, Basiuk M. ${ }^{2}$ \\ Kharkiv National Medical University1 \\ Kharkiv Regional Children's Clinical Hospital, Ukraine2 \\ https://doi.org/10.35339/ic.7.1.38-44.
}

\begin{abstract}
The study aimed to investigate the prevalence of microorganisms depending on the site of isolation and disease. The study involved 48 children aged 1 to 17 years. The patients were diagnosed with acute bronchitis (54.17\%), community-acquired pneumonia (CAP) (33.33\%), bronchial asthma (12.50\%). 173 strains of microorganisms were isolated. 106 strains $(61.3 \%)$ of Gram-positive microorganisms, 49 strains $(28.3 \%)$ of Gram-negative microorganisms, 18 strains $(10.4 \%)$ of fungi were detected. The study implied assessment of 100 samples from the nose (nasal swabs), pharynx (throat swabs) and sputum. Gram-positive microorganisms were isolated in 83 cases, Gram-negative microorganisms in 36 cases, fungi in 18 cases. The assessment showed that Staphylococcus aureus was most often isolated from patients with acute bronchitis; Gram-negative microorganisms were most often detected from throat swabs, comparing with microorganisms detected from nose swabs and sputum.
\end{abstract}

Key words: microorganisms, biofilms, respiratory diseases, children.

\section{Introduction}

Lower respiratory tract infections are still one of the leading causes of mortality in young children worldwide, accounting for 1.4 to 1.8 million deaths annually [1]. It has been hypothesized that the composition of the microbiota in the respiratory tract might be altered during respiratory diseases [2]. There is a lack of knowledge regarding the role of respiratory microbiota in susceptibility to pneumonia [3]. By the age of 2 years, almost $95 \%$ of children are colonized in the nasopharynx, in the form of a bacterial biofilm, by one of the greater than 90 serotypes of Streptococcus pneumoniae. Biofilm formation is a fundamental step in pathogenesis, as biofilms promote bacterial persistence, competence, immune evasion, and resistance to antibiotics, all while serving as reservoirs for local and invasive disease [4-7]. Another common upper respiratory tract

Corresponding Author:

Hanna Isaieva, MD, PhD student of D.P. Grynyov

Department of Microbiology, Virology and

Immunology, Kharkiv National Medical University,

Kharkiv, Ukraine.E-mail: anna1989isaeva@ukr.net opportunistic pathogen is Staphylococcus aureus. This microorganism colonizes the anterior nares and nasopharynx of 30 to $80 \%$ of individuals, often in biofilms, which serve as a reservoir for local and invasive disease [8-11]. Pneumonia caused by Klebsiella pneumoniae is characterized by an exacerbated inflammatory response, associated with excessive neutrophil and macrophage infiltration, high production of proinflammatory cytokines and severe lung injury [12, 13]. The opportunistic pathogen Pseudomonas aeruginosa is known to be an important human pathogen that produces several virulence factors. Its Quorum sensing (QS) systems are probably the best characterized among Gram-negative bacteria [14]. QS systems and biofilm formation are extemelly important components in the development of acute and chronic infections, particularly for Pseudomonas aeruginosa [15, 16]. Nontypeable Haemophilus influenzae (NTHI) biofilm formation has been associated with respiratory tract infections such as chronic rhinosinusitis and exacerbations of both chronic obstructive pulmonary disease (COPD) and cystic fibrosis [17]. Bacteria residing within 
biofilms are up to 1,000 times more resistant to antibiotics and innate immune effectors than their planktonic counterparts [18], which contributes to the chronic and recurrent nature of these biofilm-associated diseases. Consequently, there is a great need for novel ways to manage biofilmassociated NTHI infections [19].

\section{Purposes, subjects and methods:}

2.1. The purpose of the work was to investigate the prevalence of microorganisms depending on the site of isolation and disease.

\subsection{Subjects and Methods}

The study involved 48 children aged 1 to 17 years with respiratory diseases: communityacquired pneumonia (CAP), acute bronchitis, bronchial asthma, which were treated at Kharkiv Regional Children's Clinical Hospital in the intensive care unit, pulmonary department. There were 29 boys $(60.42 \pm 7.06 \%)$ and 19 girls (39.58 \pm 7.06\%). (Fig. 1).

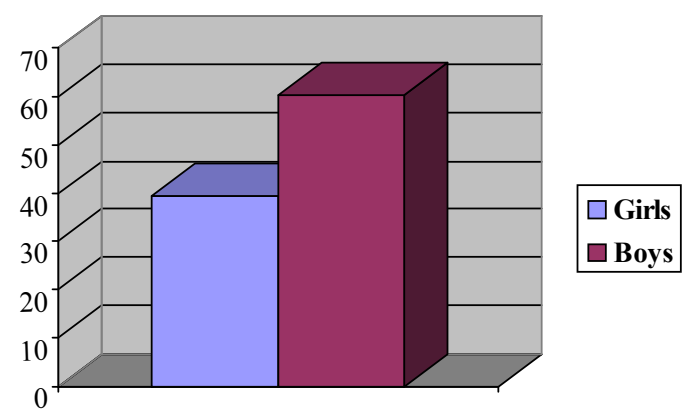

Fig. 1. Distribution of boys and girls in the research $(\%)$

Isolation and identification of microorganisms from the nose (nasal swabs), pharynx (throat swabs), and sputum was performed according to the Order No. 535 of 22 April 1985 "On unification of microbiological methods of the research used in clinical-diagnostic laboratories in hospitals". Sputum production was induced by inhalation of $5.0 \%$ hypertonic saline solution, and the sputum sample was obtained by aspirating the nasopharynx through the nostrils or by expectoration if the child was old enough to produce an adequate sputum sample [20,21].

The data were first entered in the Microsoft Excel and were analysed by SPSS V.19. Differences between places of isolation were assessed by means of $\chi^{2}$ analysis. Statistical significance was set at 0.05 .

Conflict of interests. There is no conflict of interests.

\section{Results and discussion}

Acute bronchitis developed in 26 cases

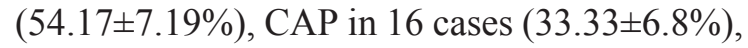
bronchial asthma in 6 cases $(12.50 \pm 4.77 \%)$ (Fig. 2).

We investigated 100 samples from the nose (nasal swabs), pharynx (throat swabs) and sputum. Gram-positive microorganisms were isolated in 83 cases, Gram-negative microorganisms in 36 cases, fungi in 18 cases. Table 1 shows that Gram-negative microorganisms in most cases were isolated from the pharynx as compared with the nose and sputum.

Overall, 173 strains of microorganisms were cultured. We detected 106 strains $(61.27 \pm 3.70 \%)$ of Gram-positive microorganisms, 49 strains $(28.32 \pm 3.43 \%)$ of Gram-negative microorganisms,

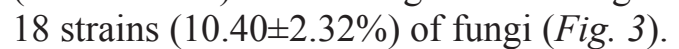

100 strains were isolated from the pharynx. There were 52 strains (52\%) of Gram-positive

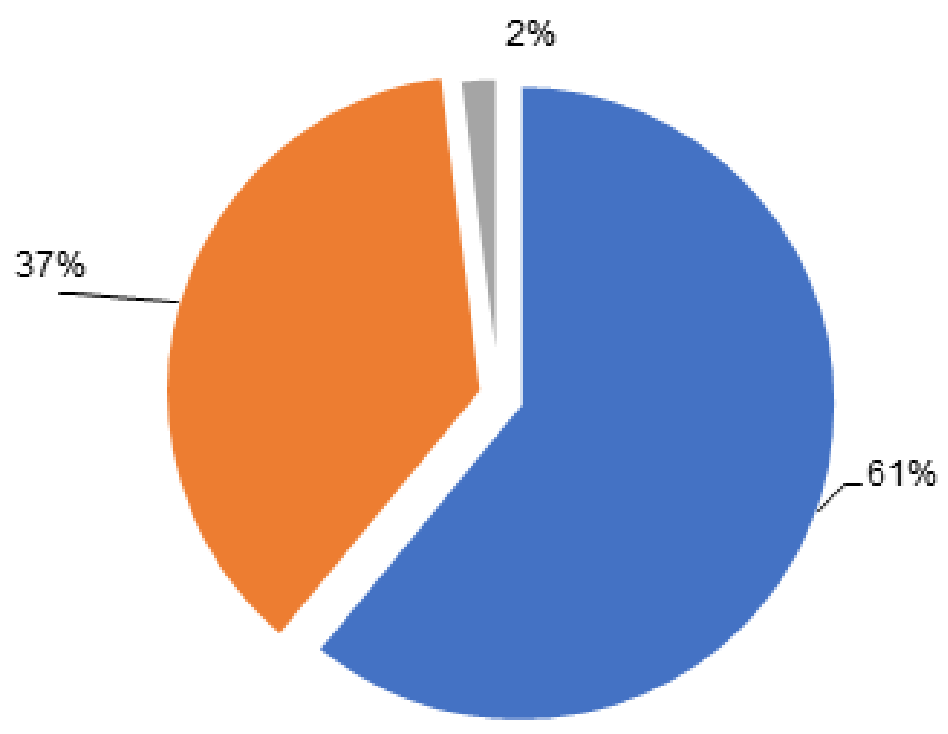

- Acute bronchitis

- CAP

- Bronchial asthma

Fig. 2. Distribution of acute bronchitis, pneumonia and bronchial asthma in the research (\%) 
Table 1

Frequency of Gram-negative organisms distribution depending on the site of detection

\begin{tabular}{|c|c|c|c|c|}
\hline & Pharynx & Nose & Sputum & $p$ \\
\hline Gram-negative microorganisms & $24(66.67 \%)$ & $8(22.22 \%)$ & $4(11.11 \%)$ & 0.002 \\
\hline
\end{tabular}

Note: differences between the samples with Gram-negative microorganisms from the pharynx, nose, sputum are statistically significant $(\mathrm{p}<0.05)$.

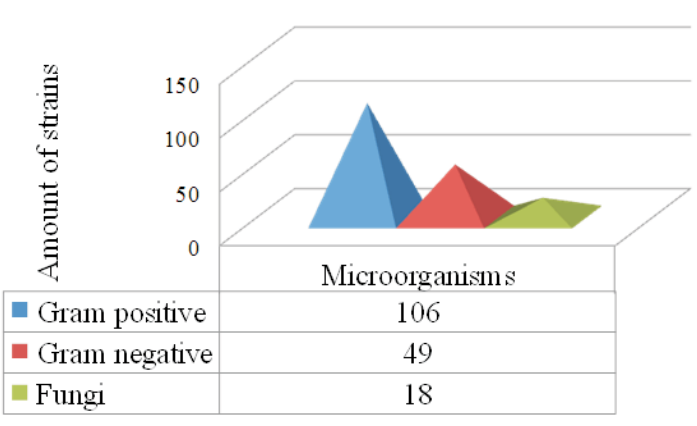

Fig. 3. Groups of microorganisms isolated from the patients

microorganisms: Streptococcus pneumoniae, viridans streptococci, group A $\beta$-hemolytic streptococci, Staphylococcus aureus, Staphylococcus epidermidis, Enterococcus faecalis (Table 2).

Gram-negative microorganisms detected 34 strains (34\%): Klebsiella pneumoniae,

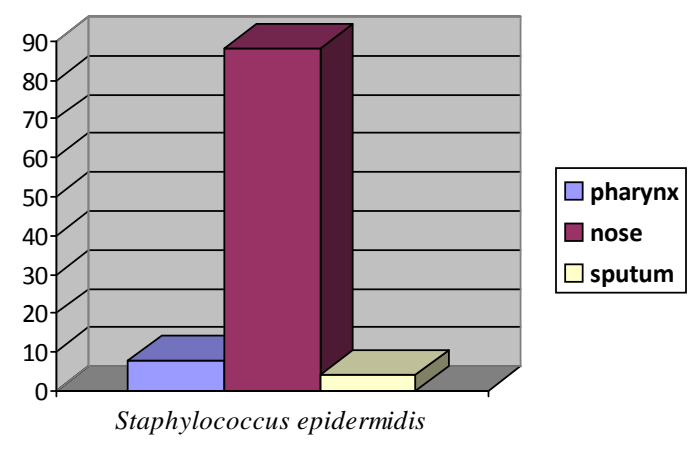

Fig. 4. The distribution of Staphylococcus epidermidis depending on the place of isolation (\%)

Note: Amount of probability type 1 error, $\mathrm{p}=0.000006<0.05$

Staphylococcus aureus predominated in patients with acute bronchitis - 23 cases (63.89\%), comparing with CAP -6 cases $(16.67 \%)$ and bronchial asthma -7 cases (19.44\%) (Fig. 5).

The number and percentage of Gram-positive microorganisms isolated

Table 2 from the pharynx (throat swabs)

\begin{tabular}{|c|c|c|c|}
\hline $\begin{array}{c}\text { Serial } \\
\text { number }\end{array}$ & Name of organism & $\begin{array}{c}\text { Number of organism } \\
(\mathrm{n}=52)\end{array}$ & Percentage of total organisms \\
\hline 1 & viridans streptococci & 17 & $32.69 \pm 6.50 \%$ \\
\hline 2 & Staphylococcus aureus & 15 & $28.85 \pm 6.28 \%$ \\
\hline 3 & group A $\beta$-hemolytic streptococci & 10 & $19.23 \pm 5.47 \%$ \\
\hline 4 & Streptococcus pneumoniae & 7 & $13.464 .73 \%$ \\
\hline 5 & Staphylococcus epidermidis & 2 & $3.85 \pm 2.67 \%$ \\
\hline 6 & Enterococcus faecalis & 1 & $1.92 \pm 1.90 \%$ \\
\hline
\end{tabular}

Neisseria spp., Haemophilus influenzae, Pseudomonas aeruginosa and other Nonfermenting Gram-negative bacilli (NFGNB) (Table 3). 14 strains of fungi were detected (14\%): Candida spp. and other fungi.

We found that group A $\beta$-hemolytic streptococci, Streptococcus pneumoniae, Klebsiella pneumoniae, Neisseria spp., Candida spp., were isolated from throat swabs more often as compared to nasal swabs and sputum (Table 4).

Staphylococcus epidermidis was most often isolated from nasal swabs - 22 cases (88\%), as compared to throat swabs -2 cases (8\%) and sputum - 1 case (4\%) (Fig 4).

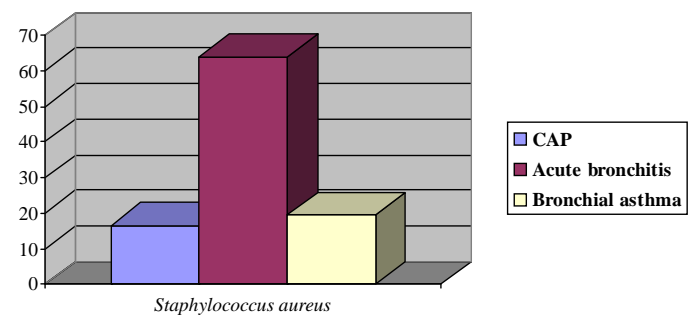

Fig. 5. The distribution of Staphylococcus aureus depending on the diagnosis (\%) Note: Amount of probability type 1 error, $\mathrm{p}=0.025<0.05$

Discussion:

We showed that Staphylococcus aureus most often was isolated from patients with acute 
Table 3

The number and percentage of Gram-negative organisms isolated from the pharynx (throat swabs)

\begin{tabular}{|l|c|c|c|}
\hline $\begin{array}{c}\text { Serial } \\
\text { number }\end{array}$ & Name of organism & $\begin{array}{c}\text { Number of organism } \\
(\mathrm{n}=34)\end{array}$ & Percentage of total organisms \\
\hline 1 & Klebsiella pneumoniae & 12 & $35.29 \pm 8.20 \%$ \\
\hline 2 & Neisseria spp. & 12 & $35.29 \pm 8.20 \%$ \\
\hline 3 & NFGNB & 3 & $8.83 \pm 4.86 \%$ \\
\hline 4 & Pseudomonas aeruginosa & 5 & $14.71 \pm 6.07 \%$ \\
\hline 5 & Haemophilus influenzae & 1 & $2.94 \pm 2.90 \%$ \\
\hline 6 & Escherichia coli & 1 & $2.94 \pm 2.90 \%$ \\
\hline
\end{tabular}

Table 4

The frequency of microorganisms distribution depending on the site of detection

\begin{tabular}{|l|c|c|c|c|}
\hline & Pharynx & Nose & Sputum & $p$ \\
\hline $\begin{array}{l}\text { Streptococcus } \\
\text { pneumoniae } \mathrm{n}=12\end{array}$ & $7(58.34 \%)$ & $1(8.33 \%)$ & $4(33.33 \%)$ & 0.0004 \\
\hline $\begin{array}{l}\text { viridans streptococci } \\
\mathrm{n}=20\end{array}$ & $17(85.0 \%)$ & $0(0 \%)$ & $3(15.0 \%)$ & 0.0004 \\
\hline $\begin{array}{l}\text { group } \text { A } \beta \text {-hemolytic } \\
\text { streptococci } \mathrm{n}=12\end{array}$ & $10(83.34 \%)$ & $1(8.33 \%)$ & $1(8.33 \%)$ & 0.015 \\
\hline Candida spp. $\mathrm{n}=16$ & $12(75.0 \%)$ & $2(12.50 \%)$ & $2(12.5 \%)$ & 0.013 \\
\hline $\begin{array}{l}\text { Klebsiella } \\
\text { pneumoniae } \mathrm{n}=18\end{array}$ & $12(66.66 \%)$ & $3(16.67 \%)$ & $3(16.67 \%)$ & 0.017 \\
\hline Neisseria spp. $\mathrm{n}=13$ & $12(92.31 \%)$ & $0(0 \%)$ & $1(7.69 \%)$ & 0.001 \\
\hline
\end{tabular}

Note: differences between specimens from pharynx, nose, sputum are statistically significant $(\mathrm{p}<0.05)$.

bronchitis. This microorganism has a lot of virulence factors, but most important in the developing respiratory diseases are toxins $(\alpha$-toxin, $\beta$-toxin, Panton-Valentine leukocidin) and biofilms formation. Theophilus K.Adiku et al. from Ghana [22], who investigated etiology of acute lower respiratory infections among children, noted that Staphylococcus aureus was a prevalent bacterial organism isolated from the throat $(8 \%)$ and from the nasopharynx $(16 \%)$. On the one hand Staphylococcus aureus, which was the most common bacterial organism in the nasopharyngeal aspirate samples, is known to occur as a normal flora in the nasopharynx of most healthy children. On the other hand, their data shows that Staphylococcus aureus may be an important cause of septicemia among children in Ghana [22]. In our research we could not prove the exact microorganism prevailing in patients with CAP, but we can suppose that without adequate treatment, bronchitis could transform to pneumonia. El Seify M.Y. et al., from Cairo, Egypt [23] showed that Staphylococcus aureus ( $n=12$; $13.3 \%$ ) was the most common typical bacterial cause of pneumonia followed by Streptococcus pneumonia $(n=7 ; 7.8 \%)$ and Klebsiella pneumoniae $(n=7 ; 7.8 \%)$. In their study, Staphylococcus aureus was found to be the most common typical respiratory pathogen causing
CAP (13.3\%) [23]. Bhuyan G.S. et al. from Dhaka, Bangladesh [24], detected microorganisms from nasal swabs in children with acute respiratory infections and demonstrated that the most commonly isolated bacteria were Streptococcus pneumoniae (39\%), Klebsiella pneumoniae (22\%), and Haemophilus influenzae (6\%). Our investigation showed that Gram-negative microorganisms in most cases detected from throat swabs as compared to microorganisms detected from nosal swabs and sputum. It may be the purpose for further investigation of virulence factors of Klebsiella pneumoniae (capsule, endotoxin, siderophores, biofilm formation), Pseudomonas aeruginosa (pigments, siderophores, elastases, biofilms formation), Haemophilus influenzae (capsule, biofilm formation) and their mechanisms of resistance to the action of antibiotics. We found that Streptococcus pneumoniae was isolated from the pharynx more often compared with nose and sputum. It is a common commensal that quiescently colonizes the upper respiratory tract, forming biofilms adhering to the epithelium of the nasopharynx, lungs, rather than planctonic cells. [25-30]. Capsule and pneumolysin are the main virulent factors that protect Streptococcus pneumoniae against phagocytosis. Honkinen M. [31], and Gentile A. [32] showed that 
Streptococcus pneumoniae and Haemophilus influenzae predominated in frequency in children with CAP [31, 32].

\section{Conclusions}

1. The present study demonstrates that group A $\beta$-hemolytic streptococci, Streptococcus pneumoniae, Klebsiella pneumoniae, Neisseria spp., Candida spp., were isolated from the pharynx more frequently as compared to the nose and sputum.

2. The study showed that Gram-negative microorganisms were most often detected in the pharynx, than in the nose and sputum.

3. Our findings suggest that Staphylococcus aureus most often was isolated from patients with acute bronchitis.

\section{References}

1. Liu L., Johnson H.L., Cousens S., Perin J., Scott S., Lawn J.E., Rudan I., Campbell H., ... Black R.E., (2012). Global, regional, and national cases of child mortality: an update systemic analysis for 2010 with time trends since 2000. Lancet, 379(9832), 2151-2161. doi: 10.1016/S0140-6736

http://dx.doi.org/10.1016/S0140-6736

2. Koppen I., Bosch A., Sanders E., van Houten M., Bogaert D., (2015). The respiratory microbiota during health and disease: a paediatric perspective. pneumonia, 6(1), 90-100. doi:10.1572/pneu.2015.6/656.

3. Sakwinska O., Bastic Schmid V., Berger B., Bruttin A., Keitek K., Lepage M., et al. (2014) Nasopharyngeal microbiota in healthy children and pneumonia patients. Journal of Clinical Microbiology 52(5):1590-1594. doi:10.1128/JCM.03280-13 http://dx.doi.org/10.1128/JCM.03280-13.

4. Charalambous B.M., Leung M.H. (2012) Pneumococcal sepsis and nasopharyngeal carriage. Current opinion in pulmonary medicine.18(3) 222-227.

https://doi.org/10.1097/MCP.0b013e328352103b.

5. Marks L.P., Reddinger R.M., Hakansson A.P., (2012) High levels of genetic recombination during nasopharyngeal carriage and biofilm formation in Streptococcus pneumonia. mBio 3(5), e0200-12. doi: 10.1128/mBio.0200-12

https://doi.org/10.1128/mBio.00200-12.

6. Marks L.R., Reddinger R.M., Hakansoon A.P. (2014) Biofilm formation enhances fomite survival of Streptococcus pneumonia and Streptococcus pyogenes. Infection and immunity 82(3), 1141-1146. doi:10.1128/IAI.01310-13

https://doi.org/10.1128/IAI.01310-13.

7. Reddinger R.M., Luke-Marshall N.R., Sauberan S.L., Hakansson A.P., Campagnaria A.A., (2018) Streptococcus pneumonia modulates Staphylococcus aureus biofilm dispersion and the transmission from colonization to invasive disease. mBio 9(1), e02089-17.

8. van den Bergh M.R., Biesbroek G., Rossen J.W., de Steenhuijsen Piters W.A., Bosch A.A., van Gils E. J., ... Sanders E.A., (2012). Association between pathogens in the upper respiratory tract of young children: interplay between viruses and bacteria. PLoS One, 7(10), e47711

https://doi.org/10.1371/journal.pone.0047711.

9. Bosch A.A., Biesbroek A.A., Trzcinski K., Sanders E.A., Bogaert D., (2013). Viral and bacterial interactions in the upper respiratory tract. PLoS One, 9(1), e1003057. doi:10.1371/journal.ppat.1003057 https://doi.org/10.1371/journal.ppat.1003057.

10. Wertheim H.F., Vos M.C., Ott A., van Belkum A., Voss A., Kluytmans J.A., van Keulen P.H., Vandenbroucke-Grauls C.M., ... Verbrugh H.A., (2004). Risk and outcome of nosocomial Staphylococcus aureus bacteraemia in nasal carriers versus non-carriers. Lancet. 364(9435), 703-705. doi: 10.1016/ S0140-6736(04)16897-9 https://doi.org/10.1016/S0140-6736(04)16897-9.

11. Esposito S., Terranova L., Zampiero A., Ierardi V., Rios W.P., Pelucchi C., Principi N., (2014). Oropharyngeal and nasal Staphylococcus aureus carriage by healthy children. BMC Infectious Diseases.14:723. doi:10.1186/s12879-014-0723-9. https://doi.org/10.1186/s12879-014-0723-9.

12. Soares A.C., Souza D.G., Pinho V., Vieira A.T., Nicoli J.R., Cunha F.G., Mantovani A., Reis L.F., ... Teixeira M.M., (2006). Dual function of the long pentraxin PTX3 in resistance against pulmonary infection with Klebsiella pneumonia in transgenic mice. Microbes and infection. 8(5).

doi:10.1016/j.micinf.2005.12.017

13. Zhang P., Summer W.R., Bagby G.J., Nelson S., (2000). Innate immunity and pulmonary host defense. Immunological reviews.173, 39-51. Retrieved from https://www.ncbi.nlm.nih.gov/pubmed/ 10719666 
14. Deep A., Chaudhary U., Gupta V., (2011). Quorum sensing and bacterial pathogenicity: from molecules to disease. Journal of Laboratory Physicians, 3(1), 4-11. doi:10.4103/0974-2727.78553

15. Byrd M.S., Bing P., Wenzhou H., Elizabeth A., Richard A., Chelsie E., Kristen E.D., Kyle M., ... Swords E., (2011). Direct evaluation of Pseudomonas aeruginosa biofilm mediators in a chronic infection model. Infection and Immunity, 79(8), 3087-3095. doi:10.1128/IAI.00057-11

16. von Rosenvinge E.C., O'May G.A., Macfarlane S., Macfarlane G.T., Shirtliff M.E., (2013). Microbial biofilms and gastrointestinal diseases. Pathogens and disease, 67(1), 25-38. doi: 10.1111/ 2049-632X.12020

17. Foreman A., Jervis-Bardy J., Wormald P.J., (2011). Do biofilms contribute to the initiation and recalcitrance of chronic rhinosinusitis? The Laryngoscope, 121(5), 1085-1091. doi: 10.1002/lary.21438. http://dx.doi.org/10.1002/lary.21438.

18. Nickel J.C., Ruseska I., Wright J.B., Costerton J.W., (1985). Tobramycin resistance of Pseudomonas aeruginosa cell growing as a biofilm on urinary catheter material. Antimicrobial Agents and Chemotherapy, 27(4), 619-624. doi:10.1128/aac.27.4.619

19. Elaine M.M., Michael O.W., Lauren O.B., (2016). Type IV pilus expression in upregulated in Nontypeable Haemophilus influenzae biofilms formed at the temperature of the human nasopharynx. Journal of Bacteriology, 198(19), 2619-2630. doi:10.1128/JB.01022-15

20. Zar H.J., Tannenbaum E., Hanslo D., Hussey J., (2003). Sputum induction as a diagnostic tool for community-acquired pneumonia in infants and young children from a high HIV prevalence area. Pediatric Pulmonology, 3(6). doi:10.1002/ppul.10302

21. Lahti E., Peltola V., Waris M., Virkki R., Rantakokko-Jalava k., Jalava J., Eerola E., Ruuskanen O., (2009). Induced sputum in the diagnosis of childhood community-acquired pneumonia. Thorax, 64(3), 252-257. doi:10.1136/thx.2008.099051

22. Theophilus K.Adiku, Richard H.Asmah, Onike R., Bamenla G., Evangeline O., Andrew A.Adjei, Eric S.Donkor, George A., (2015). Aethiology of acute lower respiratory infections among children under five years in Accra, Ghana. Pathogens, 4(1), 22-33. doi:10.3390/pathogens4010022

23. El Seify M.Y., Fouda E.M., Ibrahim H.M., Fathy M.M., Husseiny Ahmed A.A., Khater W.S., El Deen N.N.Abouzeid H.G.,... Elbanna H.S., (2016). Microbial ethiology of community-acquired pneumonia among infants and children admitted to the pediatric hospital, Ain Shams University. European Journal of Microbiology and Immunology, 6(3), 206-214. doi:10.1556/1886.2016.00022.

24. Bhuyan G.S., Hossain M.A., Sarker S.K., Rahat A., Islam T., Haque T.N., Begum N., Qadri S.K., ... Mannoor K., (2017). Bacterial and viral pathogen spectra of acute respiratory infections in under-5 children in hospital setting in Dhaka city. PLoS One, 12(3), e0174488 doi:10.1371/journal.pone.0174488

25. Hall-Stoodley L., Nistico L., Sambanthamoorthy K., Dice B., Nguyen D., Mershon W.J., Hu F.Z., Stoodley P., ...Post J.C., (2008). Characterization of biofilm matrix, degradation by DNase treatment and evidence of capsule downregulation in Streptococcus pneumoniae clinical isolates. BMC Microbiology.8:173. doi:10.1186/1471-2180-8-173

26. Gilley R.P., Orithuela C.J., (2014). Pneumococci in biofilms are non-invasive: implications on nasopharyngeal colonization. Frontiers in Cellular and Infection Microbiology, 4:163. doi:10.3389/ fcimb.2014.00163

https://doi.org/10.3389/fcimb.2014.00163.

27. Chao Y., Marks L.R., Pettigrew M.M., Hakansson A.P., (2014). Streptococcus pneumoniae biofilm formation and dispersion during colonization and disease. Frontiers in Cellular and Infection Microbiology, 4:194. doi:10.3389/fcimb.2014.000194 https://doi.org/10.3389/fcimb.2014.00194.

28. Shak J.R., Vidal J.E., Klugman K.P., (2013). Influence on bacterial interactions on pneumococcal colonization of the nasopharynx. Trends in microbiology, 21(3), 129-135. doi:10.1016/j.tim.2012.11.005 https://doi.org/10.1016/j.tim.2012.11.005.

29. Simell B., Auranen K., K?yhty H., Goldblatt D., Dagan R., O'Brien K.L., (2012). The fundamental link between pneumococcal carriage and disease. Expert Reviews of Vaccines, 11(7), 841-855. doi:10.1586/ erv. 12.53

https://doi.org/10.1586/erv.12.53.

30. Wu X., Jacobs N.T., Boizo C., Palm P., Lattar S.M., Hanke C.R., Watson D.M., Sakai F., ... Vidala J.E., (2017). Competitive dominance within biofilm consortia regulates the relative distribution of pneumococcal nasopharyngeal density. Applied and Environmental Microbiology, 83(16), e00953-17. doi:10.1128/AEM.00953-17 
31. Honkinen M., Lahti E., Osterback R., Ruuskanen O., Waris M., (2012). Viruses and bacteria in sputum samples of children with community-acquired pneumonia. Clinical Microbiology and Infection, 18(3), 300-307. doi:10.1111/j.1469-0691.2011.03603.x

32. Gentile A., Bardach A., Ciapponi A., Garcia-Marti S., P Aruj P., Glujovsky D., Calcagno J.I., Mazzoni A., Colindres R.E., (2012). Epidemiology of community-acquired pneumonia in children of Latin America and the Caribbean: a systemic review and meta-analysis. International Journal of Infectious Diseases, 16(1), e5-e15. doi:10.1016/j.ijid.2011.09.013

Received: 20-Jul-2019

Accepted: 14-Feb-2020 